\title{
Positive tuberculin test and risk of infection by Mycobacterium tuberculosis in a tuberculosis clinic settled in an upright building, in Minas Gerais, Brazil
}

\author{
SILVANA SPÍNDOLA DE MIRANDA ${ }^{1}$, ALICE CAMPOS DE OLIVEIRA², \\ ALINE XAVIER SANTOS ${ }^{2}$, DEBORAH PEREIRA PRADO ${ }^{2}$, \\ CLÁUDIA LEÃO SOARES ${ }^{2}$, RACHEL SANTOS NERY', \\ HENRIQUE CUNHA VIEIRA ${ }^{3}$, WÂNIA DA SILVA CARVALHO ${ }^{4}$
}

'Tuberculosis Clinic of the Hospital of Clinics of the Federal University of Minas Gerais, Brazil. ${ }^{2}$ Faculty of Medicine of the Federal University of Minas Gerais, Brazil. ${ }^{3}$ Medicine Undergraduate Student in the Faculty of Medical Sciences of Minas Gerais.

${ }^{4}$ Faculty of Pharmaceutics of the Federal University of Minas Gerais, Brazil.

Recibido el 3 de septiembre de 2011, aceptado el 8 de abril de 2012 .

Correspondencia a: Dra. Silvana Spíndola de Miranda

Av. Alfredo Balena, 190 Sta. Efigênia, Faculdade de Medicina/Departamento de Clínica.

Médica/Belo Horizonte, Minas Gerais, Brasil. CEP: $30130-100$

Fono: 00553188217283 E-mail: silvanaspindola@ gmail.com

\begin{abstract}
Background: Occupational Tuberculosis (TB) can lead to work absenteeism and a negative professional impact. Knowing the reactivity of the tuberculin test and the risk of $M$. tuberculosis infection among healthcare professionals is essential for the revision and reinforcement of control measures against TB transmission. Aim: To assess the reactivity of tuberculin test and risk of $M$. tuberculosis infection among healthcare professionals working in an upright building, in which a TB Reference Clinic is placed. Subjects and Methods: A tuberculosis Skin Test (TST) was done to 251 staff members of a TB clinic that did not have a previous history or suspicion of TB and that did not have a previous TST done. Among subjects with absence of reaction, repeated tests were carried out to assess booster reaction. Results: Fifty one percent of studied subjects (129) had a positive tuberculin test. The booster phenomenon was evidenced in $35.7 \%$ (68/190). The seroconversion among non-reactive subjects, subjected to a new TST after one year, was $5.1 \%$. The infection risk was 1.4. Conclusions: This study indicates an important occupational risk of infection in healthcare settings exposed to high TB incidence, and should be used to better allocate resources for infection control.
\end{abstract}

(Rev Med Chile 2012; 140: 1022-1027).

Key words: Infectious disease transmission, patient-to-professional; Latent tuberculosis; Tuberculin test.

\section{Reactividad a tuberculina en trabajadores de la salud de un centro de referencia de tuberculosis}

Antecedentes: La tuberculosis ocupacional causa ausentismo laboral. Conocer la reactividad tuberculinica de los trabajadores de la salud ayuda a mejorar las medidas de control para evitar la infección laboral con M. tuberculosis. Objetivo: Estudiar la reactividad tuberculínica de un grupo de trabajadores de la salud de un centro de referencia de tuberculosis que está ubicado en una edificación vertical. Material y Métodos: Se realizó una prueba de tuberculina a 251 empleados de una clínica de tuberculosis, que no tenían antecedentes o sospecha de tuberculosis y quienes no habian sido sometidos previamente a la prueba. Aquellos sujetos que no respondieron a tuberculina fueron sometidos a una nueva prueba para evaluar la reacción de 
refuerzo. Resultados: El 51\% de los sujetos estudiados tuvieron una reacción tuberculínica positiva. El fenómeno de refuerzo se observó en 69 de 190 sujetos (35,7\%). La tasa de seroconversión en aquellos sujetos con una tuberculina negativa en que se repitió la prueba la cabo de un año, fue de 5,1\%. Conclusiones: En este grupo de trabajadores de la salud expuestos a M. tuberculosis, hay una alta tasa de reactividad negativa a tuberculina.

T uberculosis (TB) is a Public Health problem considered as occupational infectious disease, always as occurring in healthcare professionals. TB presents serious consequences when associated to multidrug resistant (MDR) strains' dissemination ${ }^{1}$. The occupational TB could lead to work absenteeism and a negative professional impact. The knowledge about the occurrence of positive tuberculin test between healthcare professionals is one of the essential steps for revision and reinforcement of control measures against $\mathrm{TB}$ transmission. Different infection control measures, usually of simultaneous administrative and engineering character, have been implemented in industrialized countries, resulting in reduced nosocomial tuberculosis transmission. However, the effective role of individual infection control measures is difficult to establish. The implementation of such measures could be neither feasible, nor cost-effective, for resource-limited nations $s^{2-6}$.

In countries with high TB burden, the occupational risk has often been neglected and hidden by the high general population prevalence. Several studies indicate a higher TB risk between healthcare professionals, depending mainly on their time of service, professional category, and occasional utilization of respiratory protection. Other related factors are also mentioned, such as the delay in diagnosis for positive bacteriology patients, as well as the infrastructure precariousness and the barely structured work process, culminating in long shifts with doubled workday, stress and work overcharge $^{2-4}$.

Seventy three thousand cases of tuberculosis were notified in Brazil in 2009, corresponding to an incidence coefficient of 50/100,000 inhabitants. This situation places Brazil within the list of 22 countries concentrating $80 \%$ of all tuberculosis cases around the world, occupying the $19^{\text {th }}$ place in such list, according to data from the World Health Organization and the Brazilian Ministry of Health ${ }^{7,8}$. Tuberculosis is the $4^{\text {th }}$ death cause between infectious diseases, and the $1^{\text {st }}$ one in HIV positive patients. In total numbers, tuberculosis causes the death of about 4,500 victims per year.

In the State of Minas Gerais, an average of 6,085 cases/year occurred in the last six years, with an incidence coefficient of 23 cases/100,000 inhabitants; which represents the $4^{\text {th }}$ lower incidence coefficient in the Brazilian Southeastern region, and the $4^{\text {th }}$ higher TB burden in the country. The tuberculosis mortality coefficient was of 3.0/100,000 inhabitants, the percentage of cure between the new cases was of $70.2 \%$ and the proportion of treatment abandonment was of $8.5 \%$, which could contribute for the increase of resistant tuberculosis cases 9 .

In Belo Horizonte, 1,897 new tuberculosis cases were notified in 2009 (incidence coefficient of 28.88/100.000 inhabitants), with cure rates of $66.2 \%$, treatment abandonment rate of $19.7 \%$, and tuberculosis mortality coefficient of $4.3 \%$, data from the 2009 year. ${ }^{10}$ In recent studies developed in the Hospital of Clinics of the Federal University of Minas Gerais (HC/FUMG), a high occurrence of resistant TB (15.3\%) was detected, which is similar to data reported in other series analyzing the resistance profile between hospital attended patients ${ }^{11}$.

There are no recent studies evaluating $M$. tuberculosis infection in professionals who often circulate in TB reference clinics settled in upright buildings and attending patients with varied complexity grades.

The purpose of this study was to evaluate the positive tuberculin test and risk of infection in healthcare professionals, who work into upright buildings where a TB reference clinic is located.

\section{Patients and Methods}

This is a transversal, prospective, and descriptive study, developed between March 2006 and March 2008, in the Bias Forte Clinic (BFC) of the FUMG, located on the fifth floor of a seven floors 
building. The employee regularly, uses the same elevators as the clinic patients.

This study was approved by the Institutional Review Board/Independent Ethics Committee of the Federal University of Minas Gerais.

The BFC has 308 employees. Only BFC staff members accepting to develop TST, signing an Informed Consent Form (ICF), and having neither previous TB history/suspicion, nor a previously executed TST were included in this study. The sample size calculation was determined based on a multicentric study developed in Brazil, describing the prevalence of positive TST $(63 \%)$ in hospitals $^{11}$. An error of $5 \%$ and a confidence interval of $95 \%$ were admitted.

The risk analysis of TB infection was calculated using the model proposed by Ruffino-Neto $r=\frac{1}{t} \operatorname{In} \frac{N o}{N}$; where: $\mathrm{r}=$ infection risk, No $=$ number of infection-free individuals at baseline, $\mathrm{N}=$ number who remained infection-free after time $t$, $\mathrm{t}=$ time elapsed between the two Purified Protein Derivative (PPD) tests ${ }^{13}$.

The healthcare professionals were evaluated according to their respective functional categories (administrative staff, nursing professionals, physicians, psychologists, social assistants, and pharmacists, among others). A questionnaire structured and validated by REDE in TB-research/ Brazil was utilized. Symptoms of active TB, Bacillus Calmette-Guerin (BCG) vaccination history, professional contact with TB or contact occurring outside working environment, and use of NIOSH-95 or PFF2 masks (respiratory protection standardized by the Ministry of Health, Brazil $)^{8}$ were assessed during the work. The submission to any respiratory symptomatic screening, occurring at building entrance and during the study period, was also verified.

Purified Protein Derivative (PPD-RT 23 Mtb- 2 UT-Copenhagen-Denmark) was administered, in the amount of $0.1 \mathrm{~mL}$, by the Mantoux technique (intradermal). Induration reading was developed with a ruler after 72 to 96 hours, considering its longer transverse axis, and the result was expressed in millimeters. ${ }^{8}$

Clinic staff members with negative first test (TST1), < $10 \mathrm{~mm}$, were submitted to a new TT (Tuberculin Test) between one and three weeks after the first test (TST2), for evaluation of booster phenomenon. After 12 months, a third test (TST3) was developed in clinic staff members with a persisting negative $\mathrm{TT}^{14}$, and an increase $>10$ $\mathrm{mm}$ in the induration, from TST2 to TST3, was considered as tuberculin conversion ${ }^{15}$.

The treatment for LTBI (Latent Tuberculosis Infection) was indicated for BFC healthcare professionals with positive TST and a contact history shorter than two years, or tuberculin conversion without signs of active TB. The medication utilized was isoniazide $10 \mathrm{mg} / \mathrm{kg} /$ day, maximal dose of 300 $\mathrm{mg} /$ day, for 6 months ${ }^{8}$.

\section{Results}

The number of BFC healthcare professionals included in this study was 251, out of a 308 total; a fraction corresponding to $82 \%$. The average age was 40 years (17 to 69). The female gender represented $69 \%(175 / 251)$ and the male, 31\% (77/251). The female gender presented positive TST in 96/175 (55\%) and negative TST in 79/175 $(45 \%)$. For the male gender, the TST was positive in 33/77 (43\%) and negative in 44/77 (57\%). Comparing the groups, $12 \%$ more women than men exhibited positive TST.

The BFC functional categories were: cleaning workers 101/251 (55.9\%), administrative technicians 75/251 (29\%), nurses 19/251 (7.5\%), radiology technicians $7 / 251$ (2.8\%), physiotherapists $3 / 251$ (1.2\%), occupational therapists $3 / 251$ (1.2\%), social assistants $1 / 251(0.4 \%)$, pharmacists $1 / 251(0.4 \%)$, physicians $2 / 251(0.8 \%)$, and psychologists $2 / 251(0.8 \%)$.

Positive tuberculin test was verified in 51\% (129/251) of included BFC staff members. One hundred and one out of these 251 (40\%) exhibited BCG vaccination scar, and 150/251 (60\%) had no scar. Out of the scarred individuals, $46 / 101$ (45.5\%) had positive TST, while 83/150 (55.5\%) of the unscarred individuals had positive TST (Table 1). The booster phenomenon was evidenced in $35.7 \%(68 / 190)$ of the BFC staff members execu-

\section{Table 1. Prevalence of $\boldsymbol{M}$. tuberculosis infection in individuals with and without BCG vaccination scar}

\begin{tabular}{|lccc|}
\hline & $\begin{array}{c}\text { With BCG } \\
\text { scar (\%) }\end{array}$ & $\begin{array}{c}\text { Without BCG } \\
\text { scar (\%) }\end{array}$ & $\begin{array}{c}\text { Total } \\
\text { (\%) }\end{array}$ \\
\hline Workers & 101 & 150 & 251 \\
\hline TST positive & $46(45.5)$ & $83(55.5)$ & $129(60)$ \\
\hline
\end{tabular}


ting the second TST. Only $32 \%$ of the healthcare professionals executed the third TST (39/122). The conversion rate between those developing TST was of $5.1 \%(2 / 39)$. The infection risk was of 1.4 .

History of TB contact was reported in 125/251 (49.8\%) healthcare professionals. One hundred and fifteen out of these 125 (92\%) had had nosocomial contact, and 10/125 (8\%) domiciliary contact.

All the employees with positive TST, exhibiting booster phenomenon and tuberculin conversion had not symptoms of active TB, and their thoracic $\mathrm{X}$-ray did not evidence lesions suggestive of pulmonary sequel or signs of active disease.

The selection of symptomatic respiratory (SR) individuals was developed only when the patient effectively arrived to attendance floor (TB Clinic), but this selection did not occur when the patient entered the building. The healthcare professionals had started to use respiratory protection masks in the TB Clinic floor, only on occasion of its creation, in the 2001 year.

Two employees, $0.6 \%$ (2/308), had TB before the study and were excluded from it.

\section{Discussion}

This is the first work describing the LTBI in healthcare professionals working in a TB clinic settled in an upright building, as in Brazil, the majority of clinics attending TB patients are settled in horizontal and better ventilated buildings. The BFC offers a care program for patients of primary, secondary, and tertiary complexity; besides a reference clinic for TB. The BFC healthcare professionals are commonly exposed, because they circulate by elevators and corridors, close to $\mathrm{TB}$ and other diseases suspected population. A work developed in the United States of America (Washington State) draws the attention to the high risk of tuberculinic reactivity in professionals working in the non nosocomial health area. The higher risk was verified in clinics and medical consulting rooms' professionals; with an infection rate of 4.7/10,000 professionals in this area, but the respective building characteristics of their workplaces were not described ${ }^{16,17}$.

In this study, the average age was of 40 years and the predominant population was of female gender $(69 \%)$, with a proportion of positive TSTs larger between women (55\%) than between men
$(43 \%)$, in the same way as described by other authors ${ }^{5,18}$.

The positive tuberculin test at BFC was high (51\%); a fact already described for hospitals, but never described for clinics placed in upright buildings. Therefore, control measures for these settings, similar to those adopted by hospitals, should be considered. For instance: measures of administrative and/or engineering character, measures for individual protection, and creation of a TB Control Commission to act effectively. In unvaccinated individuals, the prevalence was high (55.3\%), demonstrating a high $M$. tuberculosis infection probably due to exposition, in the same way as occurring in hospitals (closed places), as the majority of BFC healthcare professionals had not a history of $\mathrm{TB}$ contact outside their work environment.

Even the TST-positive and BCG scarred individuals were, probably, infected in their workplace. Studies have demonstrated that individuals vaccinated during their childhood, and tested at an interval of 5 years or more, usually have a tuberculin reactivity pattern similar to that of their own reference population ${ }^{19,20}$. In other words, BCG vaccination in childhood does not interfere with PPD results in adulthood. Besides, the contact history rate at BFC was of $92 \%$, so it probably derives from exposition within the building. Recent studies have demonstrated the utility of Interferon Gamma Release Assay (IGRA) test for evaluation of latent M. tuberculosis infection; however, in the United States of America, authors have reported to be more cost effective to use IGRA test only in close contact, HIV seropositive individuals, and immigrants from countries with high TB prevalence ${ }^{21-23}$. In this work, we have not utilized IGRA test, as it was not validated yet for utilization in the Brazilian population ${ }^{8}$.

The high tuberculin conversion (5.1\%) and an infection risk of 1.4, three times higher than that found in the Brazilian general population, which is of 0.5 , demonstrate both a high risk of recent transmission. Works just developed within Brazilian hospitals have reported a high conversion rate, but with significant decrease when measures of nosocomial control are implemented ${ }^{24,25,11}$. It is convenient to emphasize that this just seroconverted population has higher risk to fall ill and so perpetuate TB transmission, increasing then the burden on the health system. 
The healthcare professionals with tuberculin conversion were medicated with $\mathrm{H} 300 \mathrm{mg}$ /day for 6 months, without any report of adverse reaction.

Prevention measures should be introduced in clinics with the same magnitude as BFC, in the same way as already occurring in hospitals, as these clinics do not present the typical Health Center structure corresponding to horizontal and better ventilated buildings. The use of mask and SR screening are practical and low cost measures; they should be adopted routinely by all nosocomial clinics within Brazilian hospitals, developing tuberculosis treatment within upright buildings. Such measures could decrease TB transmission in sceneries where the public health system cannot offer adequate buildings.

The limitations observed in this study were the small number of healthcare professionals that repeated the third TST, and the ignorance about the HIV status, which could influence the results.

\section{Conclusion}

This study indicates an important occupational risk of infection in health care settings with high TB incidence, and should be used to better allocate the limited resources for infection control. Moreover, it is necessary an architecture reevaluation for buildings in which TB patients are attended, in order to better avoid this disease transmission.

\section{References}

1. Joshi R, Reingold AL, Menzies D, Pai M. Tuberculosis among health-care workers in low-and-middle icome coutries: a Systematic review. PLoS Med 2006; 3: e 494.

2. Kritski AL, Dalcomo MP, Souza RB, Hollanda T, Filho PPG, Melo FAF. Tuberculose entre profissionais de saúde: risco ocupacional? J Pneumol 1993; 19 (2): 113-21.

3. Franco C, Zanetta DMT. Tuberculose em profissionais de saúde: medidas institucionais de prevenção e controle. Arq Ciênc Saúde 2004; 11 (4): 244-52.

4. Leone de Oliveira SM, Honner MR, Paniago AMM, Aguiar ESA, Venâncio da Cunha R. Prevalence of Mycobacterium tuberculosis among professionals in a University Hospital, Mato Grosso do Sul, 2004. Rev Latino-am Enfermagem 2007; 15 (6): 1120-24.

5. Lien LT, Hang NTL, Kobayashi N, Yanai H, Toyota E, Sakurada S, et al. Prevalence and Risk Factors for Tuberculosis Infection among Hospital Workers in Hanoi,
Viet Nam. PLoS ONE 2009; 4 (8): e6798.

6. Cascante JA, Hueto J. Tuberculosis como enfermedad ocupacional. An Sist Sanit Navar 2005; 28 (Supl 1): 10715.

7. WHO. Multidrug and extensively drug-resistant TB (M/XDR-TB): 2010 global report on surveillance and response. Geneva: World Health Organization; 2010.

8. Ministério da Saúde. Secretaria de Vigilância em Saúde. Departamento de Vigilância epidemiológica. Programa Nacional de Controle da tuberculose. Brasil; 2010.

9. Secretaria de Estado da Saúde de Minas Gerais. Subsecretaria de Vigilância em Saúde. Análise de situação de saúde: Minas Gerais 2010. Belo Horizonte; 2010 [acesso em 2011 Mar 22]. Available at: http://www.saude. mg.gov.br/publicacoes/estatistica-e-informacao-emsaude/analises-de-situacao-de-saude/publicacao_subsec_saude_FINAL.pdf

10. Secretaria Municipal de Saúde. Belo Horizonte; 2010 [acesso em 2011 Mar 28]. Available at: http://portalpbh. pbh.gov.br/pbh/ecp/contents.do?evento $=$ conteudo\&idC onteudo $=38934 \& \mathrm{chPl} c=38934 \&$ termos $=$ Tuberculose .

11. Froes GC, Coutinho RL, Ávila MN, Cançado LR, Spíndola de Miranda S. Perfil e seguimento dos pacientes portadores de Mycobacterium sp. do Hospital das Clínicas da Universidade Federal de Minas Gerais. J Bras Pneumol 2003; 29 (6): 365-70.

12. Roth VR, Garrett DO, Laserson KF, Starling CE, Kritski AL, Medeiros EA, et al. A multicenter evaluation of tuberculin skin test positivity and conversion among health care workers in Brazilian hospitals. Int J Tuberc Lung Dis 2005; 9 (12): 1335-42.

13. Ruffino-Netto A. Modelos epidemiométricos em tuberculose- definição de "estados" e risco de infecção. Rev de Saúde Públ 1977; 11: 188-98.

14. Ministério da Saúde. Secretaria de Vigilância em Saúde. Programa Nacional de Controle da Tuberculose. Manual de Recomendações para o Controle da Tuberculose no Brasil. Brasil; 2010 [accessed on Jan $18^{\text {th }}, 2011$. Available at: http://portal.saude.gov.br/portal/arquivos/pdf/ manual_de_recomendacoes_controle_tb_novo.pdf

15. Menzies D. Interpretetion of repeated tuberculin test Boosting, conversion, and reversion. Am J Respir Crit Care Med 1999; 159: 15-21.

16. Shah SM, Ross AG, Chotani R, Arif AA, Neudorf C (Aug 2006) Tuberculin reactivity among health care workers in nonhospital settings. Am J Infect Control 2006; 34 (6): 338-342.

17. Albuquerque da Costa PA, Trajman A, Mello FC, Goudinho S, Silva MA, Garrett D, et al. Administrative measures for preventing Mycobacterium tuberculosis infection among healthcare workers in a teaching hos- 
pital in Rio de Janeiro, Brazil. J Hosp Infect 2009; 72 (1): 57-64.

18. Menzies D. Interpretation of Repeated Tuberculin Tests. Boosting, Conversion, and Reversion. Am J Respir Crit Care Med 1999; 159 (1): 15-21.

19. Teixeira L, Maciel E, Dutra ME, Perkins MD, Johnson JL, do Valle Dettoni V. Simultaneous comparison of reactivity to purified protein derivative TR-23 and Tubersol in health care workers in Vitória, Brazil. Int J Tuberc Lung Dis 2000; 4: 1074-77.

20. Pai M, Joshi R, Dogra S, Mendiratta DK, Narang P, Dheda K, et al. Persistently elevated T cell interferon-gamma responses after treatment for latent tuberculosis infection among health care workers in India: a preliminary report. Occup Med Toxicol 2006; 1: 7.
21. WHO. The Global Plan to Stop TB 2011-2015. Transforming The Fight. Towards Elimination of Tuberculosis. Word Health Organization; 2010.

22. Linas BP, Wong AY, Freedberg KA, Horsburgh CB. Priorities for Screening and Treatment of Latent Tuberculosis infection in the United States 2011. Am J Respir Crit Care Med 2011; 184 (5): 590-601.

23. Maciel ELN, Viana MC, Zeitoune RCG, Ferreira, Fregona G, Dietze R. Prevalence and incidence of Mycobacterium tuberuclosis in nursing sytdents in Vitória, Espírito Santo 2005. Rev Soc Bras Med Trop 2005; 38 (6): 469-72.

24. Kritski AL, Conde MB, Souza GRM. Tuberculose: do ambulatório à enfermaria. $3^{\text {a }}$ ed. São Paulo: Ed. Atheneu, 2005. 